総 説

\title{
日本のカルチャーコレクションとその業務
}

\author{
永井利郎 ${ }^{1 *}$, 一木 (植原) 珠樹 ${ }^{1}$, 澤田宏之 ${ }^{1}$, 佐藤豊三 ${ }^{1}$, 青木孝之 ${ }^{1}$, \\ 山㟝福容 ${ }^{1}$, 竹谷 勝 $^{1}$, 埋橋志穂美 ${ }^{2}$, 廣岡裕吏 ${ }^{3}$, 富岡啓介 ${ }^{4}$ \\ 1 独立行政法人農業生物資源研究所遺伝資源センター \\ 2 アルバータ大学農学・食品栄養科学部 \\ 3 独立行政法人森林総合研究所森林微生物領域 \\ ${ }^{4}$ 独立行政法人農業・食品産業技術総合研究機構近畿中国四国農業研究セン夕ー
}

\section{Culture Collections in Japan and their Services}

\author{
Toshirou Nagai ${ }^{1 *}$, Tamaki Uehara-Ichiki ${ }^{1}$, Yukihiro Sawada ${ }^{1}$, Toyozo Sato ${ }^{1}$, Takayuki Aoki ${ }^{1}$, \\ Fukuhiro Yamasaki ${ }^{1}$, Masaru Takeya ${ }^{1}$, Shihomi Uzuhashi², \\ Yuuri Hirooka ${ }^{3}$ and Keisuke Tomioka ${ }^{4}$ \\ ${ }^{1}$ Genetic Resources Center, National Institute of Agrobiological Sciences, \\ 2-1-2 Kannondai, Tsukuba, Ibaraki 305-8602 \\ ${ }^{2}$ Department of Agricultural, Food and Nutritional Science, University of Alberta, \\ 116 St. and 85 Ave., Edmonton, Alberta T6G 2R3, Canada \\ ${ }^{3}$ Department of Forest Microbiology, Forestry and Forest Products Research Institute, \\ 1 Matsunosato, Tsukuba, Ibaraki 305-8687 \\ ${ }^{4}$ Western Region Agricultural Research Center, National Agriculture and Food Research \\ Organization, 6-12-1 Nishifukatsu-cho, Fukuyama, Hiroshima 721-8514
}

\begin{abstract}
Culture collections (CCs) are organizations that mainly collect strains of microorganisms to stably preserve or maintain them and distribute them to users. There are $23 \mathrm{CCs}$ in Japan ; these are mainly established in universities and national institutes, and contain a total of 411183 strains of preserved microorganisms (191692 bacteria, 50799 yeasts, 49380 fungi and others), accounting for $20 \%$ of strains preserved in CCs around the world. CCs also store information on their microorganism collections (species, location and origin of isolation, and growth conditions) in databases. These primary data for the identification of strains are open to the public via the Internet, and users can retrieve the data using searching systems offered by the CCs instead of using paper-based catalogs. In CCs, deposited microorganisms are cultured and, depending on the microbial group, freeze-drying or other freezing methods are used to prepare the microorganisms for distribution. At regular intervals, survival tests are carried out to check the quality of the preparations. In addition, CCs offer services other than distribution of their collections, such as e-mail newsletters, workshops on the handling of microorganisms, booklets on the microorganisms, and safety-deposit services for users' collections.

(Accepted Mar. 6, 2013)
\end{abstract}

Keywords : genetic resource, culture collection, database, microorganisms, JSCC キーワード：遺伝資源，カルチャーコレクション，データベース，微生物, JSCC

\section{はじめに}

植物や動物などと同じく，微生物も貴重な遺伝資源であ

る。その微生物が失われないように保存し，依頼があれば

${ }^{1} \mathbf{7} 305-8602$ 茨城県つくば市観音台 2-1-2

${ }^{2} 116$ St. and 85 Ave., Edmonton, AB, Canada T6G 2R3

${ }^{3}$ ₹ $305-8687$ 茨城県つくば市松の里 1

준 $721-8514$ 広島県福山市西深津町 6-12-1

*連絡先 (Corresponding author),nnag@affrc.go.jp
それを分譲するというのがカルチャーコレクション (Culture Collection, CC) の大きな使命である。微生物を取 り扱う多くの研究者にとっては，微生物株の入手先という のがCC に対する認識であろう。本稿では，農業生物資源 ジーンバンク ${ }^{\mathrm{i})}$ を例にとりながら，CCの簡単な歴史やそ の業務などを概説する。なお，他の遺伝資源，すなわち植 物遺伝資源（種子，栄養体等）や動物遺伝資源（精子，卵 子等）を取り扱っている機関もあるが，本質的には CC と 
同じである ${ }^{122}$.

\section{日本・外国のカルチャーコレクション}

微生物株を研究者個人が収集・保存し, それを他の研究 者に分讓することは昔から行われてきた。そのような個人 サービスが発展し, 微生物株を収集・保存し, 分譲すると いう明確な目的意識を持って組織化されたものが CC であ る。個人レベルでのそのようなサービスは継続性の点で脆 弱であるが, 組織的に運営することで, 継続性が格段と高 まる。このような組織, CC は, 19 世紀末から 20 世紀初頭 にかけて次々と世界各地で設立された。世界最古と言われ るチェコスロバキアの CC が 1890 年に, 米国の ATCC (American Type Culture Collections) ${ }^{\mathrm{ii})}$ の前身が 1911 年, オランダの CBS (Centraalbureauvoor Schimmelcultures, Filamentous fungi and Yeast Collection) ${ }^{i i i)}$ が 1903 年, 英国 の IMI (International Mycological Institute, CABI Genetic Resource Collection) $)^{\text {iv })}$ の前身が 1920 年という具合にであ る ${ }^{3 / 4)}$. 現在, 国際協力機構として WFCC (World Federation for Culture Collections, 1970 年設立 ${ }^{\mathrm{v})}$ が結成されてお り，それに加盟しているCCは 72 力国の 629 団体に上っ ている。

日本では，欧米での CC 設立とほぼ同時期，1904 年の醇 造試験所にさかのぼる5 . そして, 1927 年には日本で最初
の微生物株目録が南満州鉄道(株)中央試験所より出版され ている6). それ以降, 各大学や国立研究所内に多くの CC が 作られていくこととなる。1951 年に, 日本微生物株保存機 関連盟（Japanese Federation of Culture Collections of Microorganisms, JFCC）が作られ，国内のCCの体制作り，そし て近代化に寄与していくことになる6).JFCCは, 1974 年の 組織改正を経て個人会員制を導入し，更に1993 年には日 本微生物資源学会（Japan Society for Culture Collections, JSCC $)^{\mathrm{vi})}$ として学会組織に変革した。現在，機関会員であ るCC を中心に, 個人会員, 賛助会員から構成され, 学会 誌を出版し, 大会を開くなど活動の輪を広げている4! ここ 最近, 日本の CC のいくつかが整理統合されるという大き な動きがあった，日本のCCとして世界的にも著名であっ た IFO (Institute of Fermentation, Osaka) と, IAM（the Institute of Applied Microbiology, University of Tokyo) は, それぞれ微生物株を NBRC (NITE Biological Resource Center) ${ }^{\text {vii) }}$ と JCM (Japan Collection of Microorganisms,

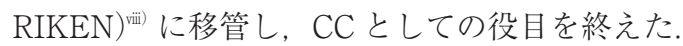

現在日本で活動しているCC を表 1 に挙げた，表の中の アクロニムとは, 微生物株の登録番号の最初に付される機 関固有の略称であり，多くはその機関の英名に基づく頭文 字が用いられている。組織の変遷を受けた CCでは，必ず しも現在の機関の略号とアクロニムが合致しているとは限

表 1 日本のカルチャーコレクション

\begin{tabular}{|c|c|c|c|}
\hline $\begin{array}{l}\text { アクロニム } \\
\text { /機関略号 }\end{array}$ & 名称 & $\begin{array}{l}\text { 保存 } \\
\text { 点数 }\end{array}$ & 備考 \\
\hline AHU & 北海道大学大学院農学研究院応用生命科学部門菌株保存室 & 1448 & 応用菌学講座由来 \\
\hline ATU & 東京大学大学院農学生命科学研究科応用生命工学専攻 & 1334 & \\
\hline FFPRI & 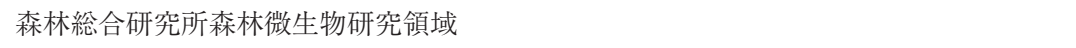 & 408 & きのこ類 \\
\hline GTC & 岐阜大学大学院医学系研究科病原微生物遺伝子資源保存センター & 13560 & 病原微生物 \\
\hline HUT & 広島大学大学院先端物質科学研究科分子生命機能学専攻微生物遺伝資源保存室 & 1499 & \\
\hline IFM & 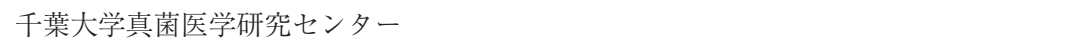 & 20140 & 病原微生物 \\
\hline IID & 東京大学医科学研究所感染症国際研究センター病原微生物資源室 & 1440 & 病原微生物 \\
\hline IMRG & 群馬大学医学部薬剤耐性菌実験施設 & 62120 & 薬剂耐性菌 \\
\hline ISU & 石巻専修大学理工学部基礎理学科 & 776 & けかび類 \\
\hline JCM & 理化学研究所バイオリソースセンター微生物材料開発室 & 20708 & タイプ株 \\
\hline NBRC & 製品評価技術基盤機構バイオテクノロジー本部生物遺伝資源部門 & 126732 & タイプ株・特許微生物 \\
\hline NEKKEN & 長崎大学熱帯医学研究所 & 267 & 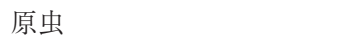 \\
\hline MAFF & 農業生物資源研究所ジーンバンク & 28333 & 食品微生物 ·植物病原菌 \\
\hline NIES & 国立環境研究所微生物系統保存施設 & 2324 & 藻類 \\
\hline NIG & 情報・システム研究機構国立遺伝学研究所系統生物研究センター原核生物遺伝研究室 & 55930 & \\
\hline NRIC & 東京農業大学応用生物科学部菌株保存室 ～～～～～～～～～～～～～～ & 7731 & 食品関連微生物 \\
\hline OUT & 大阪大学大学院工学研究科生命先端工学専攻 & 28834 & \\
\hline RIB & 酒類総合研究所微生物研究室 & 725 & 酒類醉造関係微生物 \\
\hline RIFY & 山梨大学工学部ワイン科学研究センター & 2800 & ワイン醉造関係酵母 \\
\hline RIMD & 大阪大学微生物病研究所感染症国際研究センター病原微生物資源室 & 11496 & 病原微生物 \\
\hline TIMM & 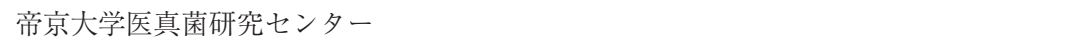 & 9782 & 病原微生物 ～～～～～～～～～等 \\
\hline TUFC & 鳥取大学農学部附属菌類きのこ遺伝資源研究センター & 新規 & きのこ類（菌草研究所由来） \\
\hline TAMA & 玉川大学学術研究所菌学応用研究センター & 新規 & \\
\hline
\end{tabular}

保存点数は日本微生物資源学会誌，28，177（2012）による. 
表 2 日本および世界のカルチャーコレクションが保有する 微生物株数とその内訳

\begin{tabular}{lrr}
\hline \hline \multicolumn{1}{c}{ 微生物種類 } & JSCC $^{\mathrm{a})}$ & WFCC $^{\mathrm{b})}$ \\
\hline 細菌 & 191692 & 964531 \\
酵母 & 50799 & - \\
糸状菌 & 49380 & 537768 \\
放線菌 & 11285 & - \\
動物培養細胞 & 2547 & 8746 \\
藻類 & 1850 & - \\
ウイルス & 889 & 34852 \\
シアノバクテリア & 763 & - \\
アーキア & 762 & - \\
原生動物 & 407 & - \\
バクテリオファージ & 360 & - \\
植物培養細胞 & 15 & - \\
その他) & 100434 & - \\
\hline 計 & 411183 & 2056399
\end{tabular}

a） 2012 年 3 月現在（日本微生物資源学会誌，28，177 (2012) より)

b) WFCCでは, Bacteria, Fungi, Virus と Cell line の 4 種類 に類別して発表されている。直接対応が無い項目はーで示 している Cell line は便宜上動物培養細胞の行に記載した。 2013 年 1 月現在. http://www.wfcc.info/ccinfo/より.

c）マイコプラズマ, リケッチア, ウイロイド, 線虫, 原虫, 心゙ クターなど

らない，例えば，農業生物資源ジーンバンクの機関の略号 は NIAS (National Institute of Agrobiological Sciences, 農 業生物資源研究所）であるが, 設立当初の事業実施主体で ある農林水産省（Ministry of Agriculture, Forestry and Fisheries）にちなみ, MAFF というアクロニムが現在も使 用されている。CCに保存されている微生物株を指定する には，アクロニムの後ろに登録番号を付けて，例えば, MAFF 110112 という具合に表記する。それぞれの CC は その運営母体の影響を強く受け，おのずと母体の特色がそ のまま収集対象に表われている（表 1)。

表 1 では省略したが，それぞれのCCのサイトへは JSCCのサイト ${ }^{\mathrm{ii})}$ からたどるのが便利である。なお世界各 国の CC のサイトへは WFCCのサイトv ${ }^{\mathrm{v}}$ からたどること ができる。

JSCC 傘下の CC が保有する微生物株の延べ総数は, 411 183 株（2012 年 3 月現在）で，そのうち細菌がほぼ半分を 占める (表 2). 同一微生物株が広く複数の CC に保存され ていることもあるので，実質的な微生物株数はいくぶん下 回るものと思われる。表中の「その他」にはウイロイド, リケッチア, 線虫, 原虫, ベクターなどが含まれる。ちな みに, WFCC 傘下の CC の保存微生物株総数も併せて示し た、WFCC が公開している保存株数のカテゴリーはJSCC のそれと異なって4 カテゴリーに集約しているので正確に は対応が付けられないが，おおよその傾向は見て取れる。

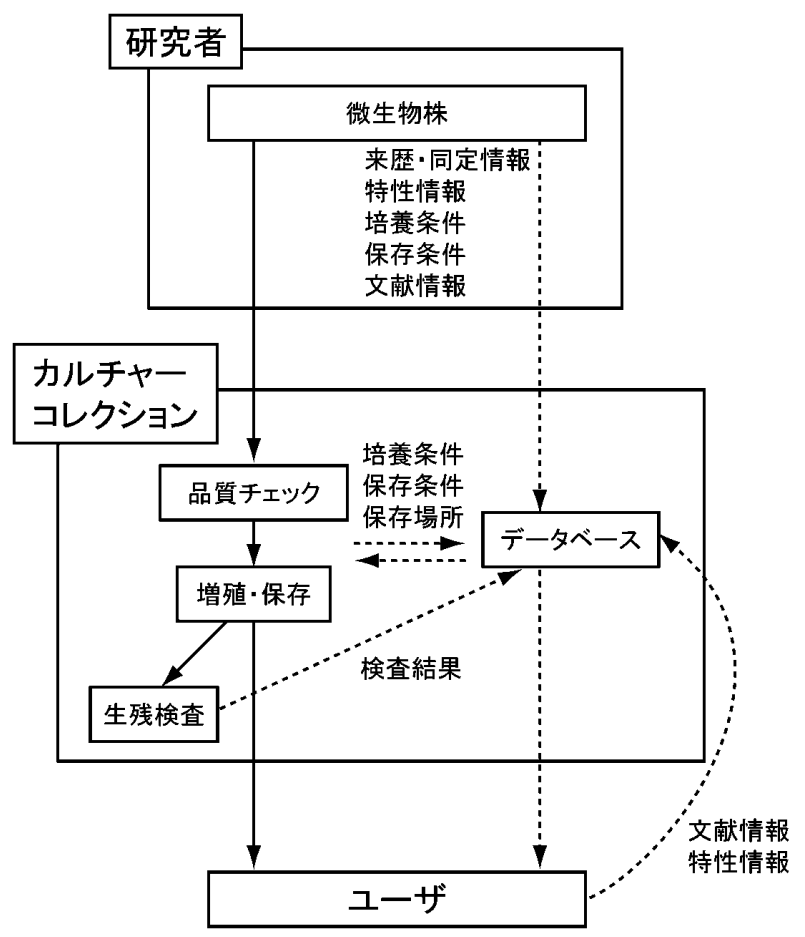

図 1 業務のフローチャート

微生物株を取り扱う作業の流れ（実線）と，その微生物株の情 報に関わる作業の流れ（点線）を示した。

単純に保存総数から計算すると，日本国内には実に世界の CC が保有する微生物株の $20 \%$ が保存されていることに なる、日本は，古より醗酵という形で微生物を利用してき た実績があり，そのことが数字の上にも表われている。

\section{$\mathrm{CC}$ 業務の概略}

カルチャーコレクションの業務には, 微生物株そのもの を扱う業務と，それに付随する情報を扱う業務があり，そ れらが密接に関連しながら作業が進んでいく（図 1).

CC が微生物株を収集（第三者からの寄託を含む）する と, その微生物株について品質を確かめた後に, 増殖し保 存標品を作製する。そして一定期間の保存を経たのちに品 質検査（生残検査）を行い，品質に問題が無ければ分譲す るまで保管庫で保存する。情報については，上記の作業に 先行して, 微生物株のデータをデータベースに登録し, 増 殖・保存・検査などの作業が円滑に進むようにしている. データベースには CC 内で新たに生じたデータ（保存, 品 質に関するデー夕など）も逐次蓄積・更新されていく。こ の 2 つ作業の流れの詳細を以下に述べる.

\section{微生物株の増殖・保存方法}

収集した微生物株は，収集者からの情報などに基づき， 適正な方法で培養を行う。種類ごとのおおよその培養条件 を表 3 に示す。スラント培養の状態にある糸状菌や細菌 は，まず平板培地に移植し培養する。そして平板上で微生 
表 3 微生物種の培地条件と保存方法

\begin{tabular}{|c|c|c|c|c|}
\hline 微生物種 & & 保存方法a) & 培地 ${ }^{b}$ & 保護剤( ) \\
\hline \multirow[t]{2}{*}{ 細菌 } & 一般細菌 & $\mathrm{F}, \mathrm{FD}$ & 標準寒天培地 & $1.5 \% \mathrm{MSG}+10 \%$ スキムミルク \\
\hline & 乳酸菌 & $\mathrm{F}, \mathrm{FD}$ & $\mathrm{BCP}$ & $1.5 \% \mathrm{MSG}+10 \%$ スキムミルク \\
\hline 放線菌 & & $\mathrm{F}, \mathrm{FD}$ & YSA & $0.005 \%$ エーロゾル OT+1.5\%MSG+10％スキムミルク \\
\hline \multirow[t]{2}{*}{ 糸状菌 } & 一般糸状菌 & $\mathrm{LN}$ & PDA & $10 \%$ グリセリン \\
\hline & きのこ & $\mathrm{LN}$ & IFO-7, PDA & $10 \%$ グリセリン \\
\hline 酵母 & & $\mathrm{F}, \mathrm{FD}$ & YM & $1.5 \% \mathrm{MSG}+10 \%$ スキムミルク \\
\hline バクテリオファージ & & $\mathrm{F}, \mathrm{FD}$ & 標準寒天培地 & $1.5 \% \mathrm{MSG}+10 \%$ スキムミルク \\
\hline
\end{tabular}

a) F，凍結；FD，凍結乾燥， LN，液体窒素気相中凍結

b）培地組成（いずれも $1.8 \%$ になるように寒天を加える）：標準寒天培地（日水製薬）, BCP (BCP 加プレートカウントアガー ル, 日水製薬), $\mathrm{YSA}\left(0.2 \%\right.$ 酵母エキス, $1.5 \%$ 可溶性でんぷん, $\left.0.05 \% \mathrm{~K}_{2} \mathrm{HPO}_{4}, 0.05 \% \mathrm{MgSO}_{4} \cdot 2 \mathrm{H}_{2} \mathrm{O}\right), \mathrm{PDA}$ (BD), IFO-7 (0.5\% エビオス, $2 \%$ グルコース)，YM (0.3\%酵母エキス，0.3\%麦芽エキス，0.5\% ペプトン，1\%グルコース) c） MSG，グルタミン酸ナトリウム

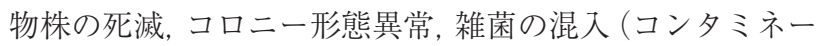
ション）などが無いかを精査する，更には同定にかかわる DNA 塩基配列を調べ, 誤同定の疑いが無いかを確認し, これらの DNA 情報も公開している。ただし, その微生物 の特性（例えば酵素産生，物質生産性など）については必 ずしもCCにおいて確認しているわけではなく，保証はさ れていないことの方が多い。保存中の微生物株の特性の維 持管理そして保証については，ユーザにとっては要望の多 いところであるが, 一つ一つの株について行うにはかなり の労力と時間が必要になり, 確認できていないのが現状で ある. 微生物株に異常がないことを確認したら, 当該微生 物株をスラント培地や平板培地に培養し, 保存標品を作製 する。

微生物を保存する方法には微生物種類によりいくつかの 方法がある (表 3). 以下, 食品に関係の深い微生物種類, すなわち細菌, 酵母, 糸状菌の保存法について詳述する. なお，生きた状態のまま新しい培地へ微生物株を植え継い でいく継代培養は, コンタミネーション, 死滅や変異の危 険性が高いため, 卵菌類（植物病原微生物の一群）など難 保存性の微生物株を除いては通常は行われていない.

細菌・酵母（放線菌やバクテリオファージを含む）は凍 結乾燥法と凍結保存法により保存している7?. 凍結乾燥法 は，培養した細胞を凍結保護剂に懸濁し，ガラスアンプル に分注（図 2A）した後に凍結乾燥し, 真空下でアンプルを 封入する方法である (図 $2 \mathrm{~B}, \mathrm{C}$ ). 凍結保護剤は, 凍結中に 細胞が損傷しないために加えるもので, $10 \%$ スキムミルク $-1.5 \%$ グルタミン酸ナトリウム溶液が多用される。凍結 保存法は, 凍結乾燥法に用いた残りの懸濁液を凍結用 チューブに移し，そのままディープフリーザ内で保存する 方法である。一般的な研究室ではグリセロールストックで 細菌が保存されることが多いが，それに相当するものであ る。他には, 懸濁液の状態から真空乾燥する L-乾燥法 (drying from the liquid state) が, 凍結処理に弱い微生物の
保存方法として知られている ${ }^{8}$. 滅菌水で菌体を希釈した まま低温で保存する水保存法もある ${ }^{9}$.

糸状菌は主として凍結法により保存している ${ }^{10)}$. 糸状菌 を寒天平板一面に増殖させた後，滅菌ストロー（およそ6 $\mathrm{mm}$ 径) で菌糸を寒天培地ごと丸くくりぬき，それを $10 \%$ グリセリンの中に入れる（図 2D），多く入れすぎるとグリ セリンが薄まるので，入れるのは少数にとどめる。冷蔵庫 に入れ，低温で馴化した後，ディープフリーザに移し凍結 する。なおプログラムフリーザで凍結速度を制御しながら 凍結する方法もある ${ }^{11}$. 標品が完全に凍結した後, 液体窒 素の気相に移す（図 $2 \mathrm{E}, \mathrm{F}$ )。動物の精子や始原生殖細胞 など, より低温が必要な場合は, 液体窒素に完全に浸すが, 糸状菌の場合は，液体窒素に浸すと液体窒素が凍結標品内 に混入し，細菌などのコンタミネーションの危険性がある ので，それを避けるために気相中に保存している．液体窒 素気相の温度は $-165^{\circ} \mathrm{C}$ 前後であり, 糸状菌の保存には充 分である。他の保存方法としては，スラント培養で更に機 密性を高め, 保存性を良くした流動パラフィン重層法やダ ブルキャップ法（シリコン製のキャップでふたをする方 法), 滅菌水に菌糸の着生した寒天片を入れてそのまま低 温で保存する水保存法がある ${ }^{12}$.

微生物株の長期保存には，通常，分譲用，生残検査用と 永久保存用の 3 種類の保存標品を作製する。分譲用は微生 物株の分譲頻度により作製すべき本数が決定されるのに対 して, 永久保存用としては 2 本程度作製されることが多い. 生残検査用は一定期間保存後に微生物株が正常に保存され ているのかどうかの試験 (生残検査)を行うためのもので, 想定される検査回数に応じて作製する，例えば，農業生物 資源ジーンバンクでは 1 か月および 1 年後の 2 回の定期的 な生残検査を行っている（図 $2 \mathrm{G}$ ). 多くの微生物株では 1 カ月間の保存が成功すれば，その後の保存もほぼ良好であ る (表 4 $)^{1314}$ ）表 4 では, 食品微生物とは直接関係ないが, 参考のため凍結保存の難しい微生物である卵菌類の成功率 


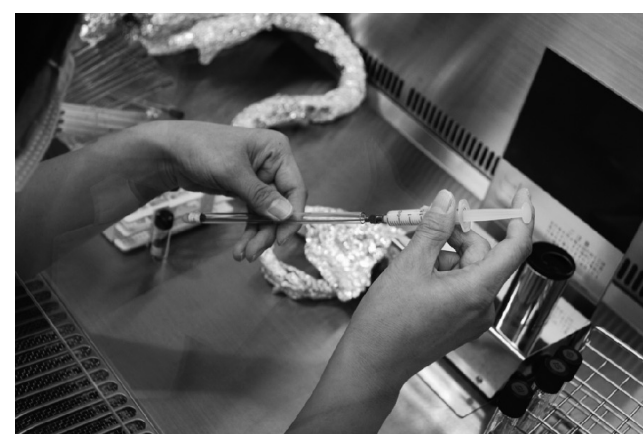

A. 分注

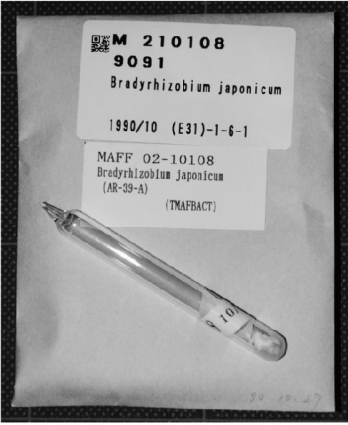

C. アンプルと封筒

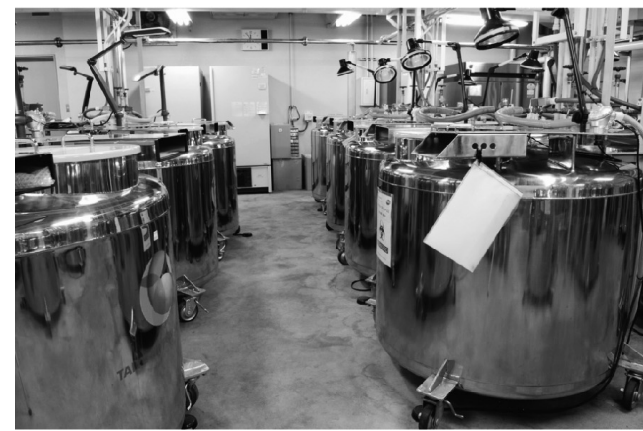

E. 液体窒素タンク

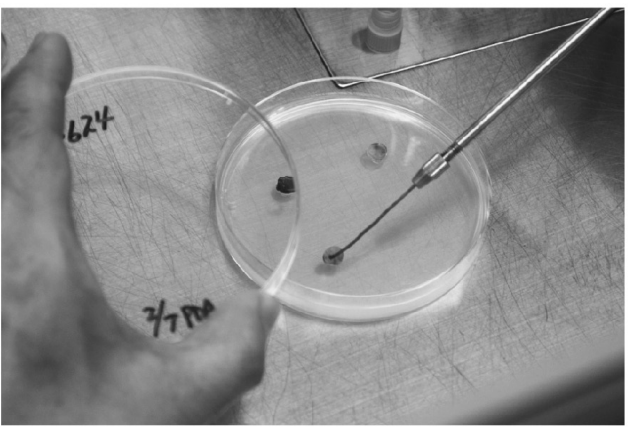

G. 生残検査

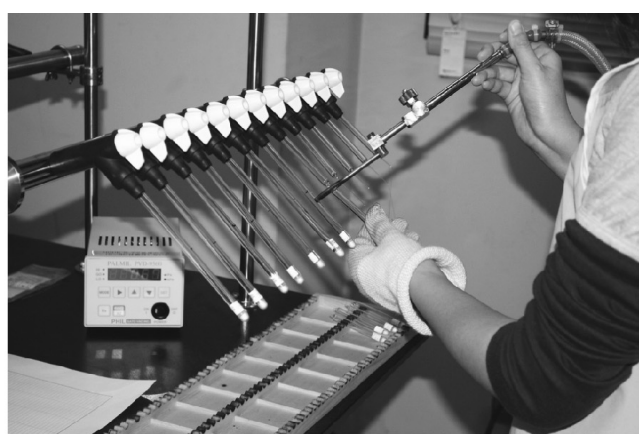

B. アンプルの切断

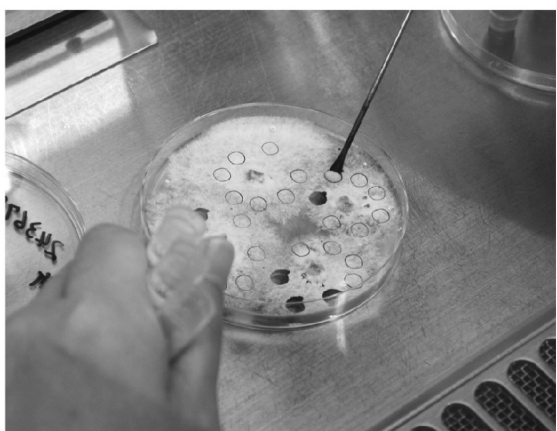

D. 打ち抜き

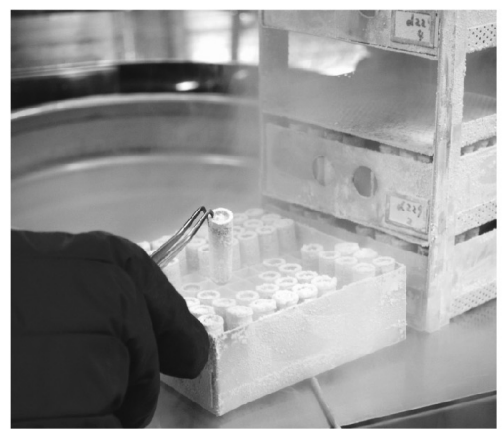

F.ラックとチューブ

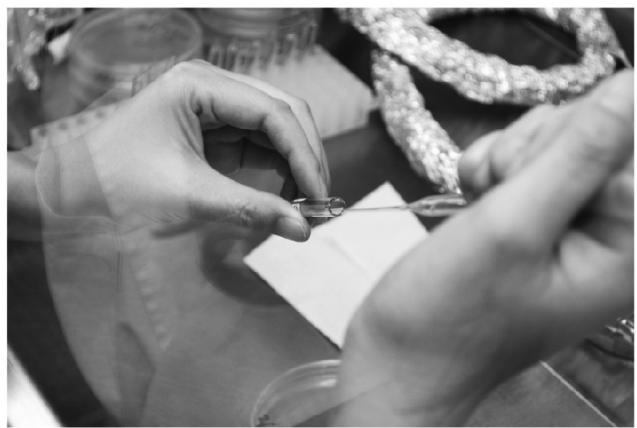

H. 復元

図 2 保存設備と作業

A, 細菌の懸濁液をガラスアンプルへ分注； B, 真空凍結乾燥機にとりつけたアンプルをガスバーナーで熔封； C, 製作したアンプルの標品とそれを入れる封筒。学名等が表示されており, 左上にはロット情報をコード化した二次 元バーコードが見える； D, 糸状菌の保存標品作製。平板培養した糸状菌を寒天ともに打ち抜いて, グリセリンの 入ったチューブに入れる。 E，液体窒素タンク； F，液体窒素タンクに収められているラックとチューブ； G，生残 検査のため, D で作製したチューブから寒天片を平板培地に移植している； H，細菌の生残検査のために凍結乾燥 標品を滅菌水に懸濁し, 平板培地に移植している。 


\section{表 4 保存に成功した微生物株の割合}

\begin{tabular}{lccc}
\hline \hline & & \multicolumn{2}{c}{ 保存に成功した菌株の割合 } \\
& 保存株数 & 1ヶ月後 $(\%)$ & 1 年後 $(\%)$ \\
\hline 酵母 & 101 & 99.0 & 99.0 \\
細菌 & 1996 & 99.9 & 99.8 \\
放線菌 & 237 & 100.0 & 100.0 \\
糸状菌 & 6681 & 99.3 & 98.5 \\
卵菌類 & 414 & 72.5 & 63.8 \\
\hline
\end{tabular}

文献 14 より改変

も掲載した。

幸いに, 食品関連微生物（酵母, 䞤菌, 乳酸菌や納豆菌) は微生物遺伝資源の中でも, 非常に保存しやすい微生物で あり，適切に管理している場合は死滅するということはほ とんど無い.

\section{情 報}

微生物株に関する情報はすべてデータベースで管理され ており，微生物株のアイデンティティに関わる情報（来歴 情報）などはインターネットを通じて検索することができ る（図 3） 1516)．ブラウザの限られた面積の画面上では多く の微生物株についての詳細情報を閲覽することは難しいの で，個別の微生物株について別途詳細情報を表示している (図 3B の内部ウィンドウ). CCによっては, インターネッ トショッピングではおなじみであるが，ヒットした微生物 株を直接カートに入れて（図 3B では，内部ウィンドウの 下にある「配布申込」の「可」の文字のところをクリック する)，後でまとめて分譲の手続きに移れるように工夫が なされているところもある。インターネットの世界は進歩 が速いので，今後，最新の技術を取り入れ，よりユーザに とって使いやすいシステムに発展していくことと考えられ る。検索システムは各 CC で個別に提供されているが, JSCCでは, CC 機関会員の保存株を横断的に検索できるシ ステムを開発しており，ユーザの利便性を高めている，現 在は検索対象が 8 機関の保存微生物株に限られているが, 将来は対象を拡大する方向にある17.

微生物株に付随する情報としては，来歴情報の他に特性 情報や文献情報が重要である。特性情報には，酵素生産性 や物質生産性，製パン特性などの情報がある。しかしなが ら，その特性を表現する方法は，研究者個人や特性の種類 により異なっているため，正規化するのが困難であり，細 かな情報まで公開しているCC は少ない.多くの CC は, 例えばアミラーゼ生産という項目のみが揭げられているだ けで，その内容（生産量，条件等）まで梁く踏み込んで公 開しているところはほとんどない，また，その情報の形態 も，単なる数值もしくは文字列にとどまらず，塩基配列情 報，写真，表，グラフなど多岐にわたることも，特性情報 の公開を難しくしている要因である，特性に関する情報
は，産業や科学の発展に寄与するものであるので，今後， 効果的に特性情報を公開する方法の開発が望まれる。むし ろ現在は，その欠点を，その微生物株に関する文献情報を 公開することで補っている，微生物株の詳細情報（図 3B） では，その微生物株に関する文献情報が，さながら論文の 引用文献のように表示される。更に，農業生物ジーンバン クでは, これらの文献にアクセスできるように，DOI (Digital Object Identifier，デジタルオブジェクト識別子) や，それが無い場合には文献ファイルやその揭載誌の発行 元の URL (Uniform Resource Locator) を公開している（図 3B 内部ウィンドウの文献情報の後ろのアイコン).

作製した保存標品の情報は，業務にかかわる重要な情報 の 1 つである。ある微生物株について保存標品を作製する たびにロット番号を付け，それを介してデータベース内の いろいろな情報（微生物株の番号，保存日，培養抢よび保 存条件, 保存場所のアドレス, 数量など）にアクセスする ことができるようになっている ${ }^{18199 .}$. 多くの CCでは，それ ぞれの標品にロット番号などの情報を記録したバーコード のシールを貼り付け，作業場からそのバーコードを介して 上記のデータにアクセスできるように管理している（図 $2 \mathrm{C})^{20) \sim 22 \text { ? }}$.

微生物株を増殖・保存する際は，寄託者から知らされた 増殖・保存条件に関わる情報を参照しつつ，またそれより も適した条件があれば，その情報をデータベースにフィー ドバックし，次回の増殖・保存に活かすことで，さらなる 業務の効率化を図っている (図 1, 両方向の点線矢印)。保 存標品の生残検査の結果もデータベースに蓄積し, 分譲や, 増殖作業の計画などに利用している（図 1).

以上の情報は CC 内部で互いに関連し合いながら，大き な情報ネットワークを形成しており，一方向に流れる単純 なものではない．20 数年も昔には紙媒体の台帳を利用し てこれらの情報を管理していたが，現在ではコンピュータ とデータベースソフト無しには管理できないほどの膨大な 量になっている

\section{分変}

分讓の依頼があると, 生残検査結果に基づいて最適な ロットを選択した後，ロットの保存場所の情報をもとに保 管庫より標品を取り出し，分譲依頼者へ送付する。安定性 の高い凍結乾燥標品は常温で送付している。しかしなが ら，スラント標品や糸状菌で解凍した標品については，配 送中に温度上昇による影響を受けやすいため，特に夏場で は低温で送付している。いずれも, 配送中の破損に備えて, ショック吸収性の容器に入れ, 郵便規則に則り送付してい る。な㧍，外国への分譲の場合，万国郵便条約に規定され た方法で送付しなれればならない23242)。また病原体など輸 出規制されている微生物の場合，あらかじめ輸出許可申請 が必要な場合がある23. 


\section{$A$ 微生物遺伝資源の検索}

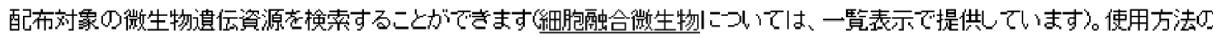
詳細に一つ、ては、微生物遺伝資源换索の手引きをご参照ください。

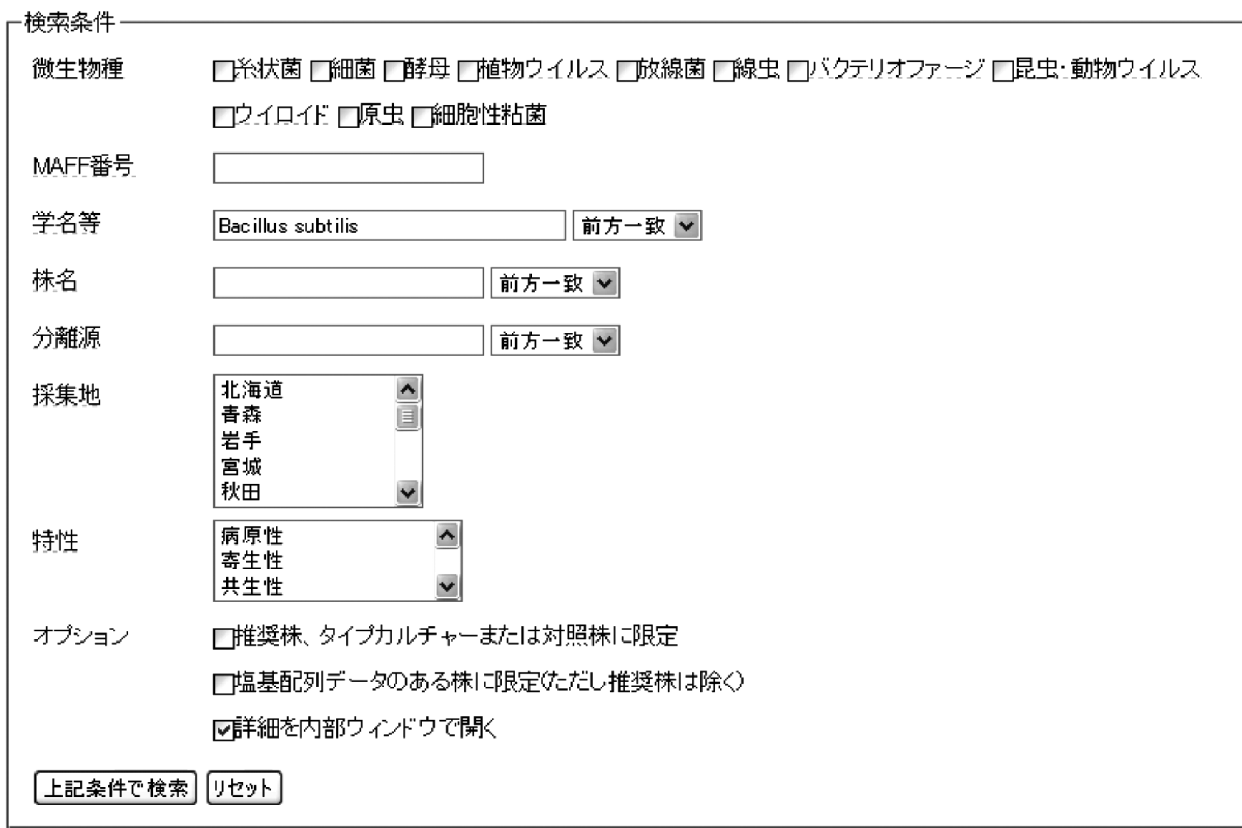

\section{$\mathrm{B}$ 微生物遺伝資源の検索}

使用方法の詳細についてては、微生物遺伝資源搔索の手引ききをじ参照ください。 26件が該当しまた娄。1マ/2

\begin{tabular}{|c|c|c|c|c|c|c|c|c|c|}
\hline MAFF番号 & 学名 & & & 株名 & 分㒕源 & 採集地 & 偪考 & 配不 & \\
\hline$\underline{111130}$ & \multicolumn{2}{|c|}{ Aspergillus aryzae } & & & & 不明 & & \multicolumn{2}{|c|}{ =申込 } \\
\hline$\underline{111175}$ & \multicolumn{2}{|c|}{ Aspergillus aryzge } & & 敖-3 & 味増用種凊 & 不明 & & \multicolumn{2}{|c|}{ :申込 } \\
\hline$\underline{111177}$ & \multicolumn{3}{|c|}{ Aspermill. . . } & 䎂上下 & 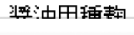 & 不朋 & & \multicolumn{2}{|c|}{ a中is } \\
\hline 111178 & Aspe: & MAFF: 111561 & & & & & & & $x$ \\
\hline$\overline{111264}$ & Aspes & MAFF番号 & 111561 & & & & & & 스 \\
\hline$\underline{111266}$ & Aspes & 微生物種類 & 系状团囷 & & & & & & \\
\hline 111561 & Aspes & 学名 & Aspergilh & (Ahlbu & & & & & \\
\hline$\underline{111563}$ & Aspen & 登録時学名 & Aspergill & & & & & & \\
\hline$\underline{111608}$ & Aspen & 可正者 & 新國传幸 & & & & & & \\
\hline$\underline{111609}$ & Aspen & 舟何正苩 & 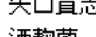 & & & & & & \\
\hline$\underline{111610}$ & Aspen & 个五 & 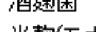 & & & & & & \\
\hline$\underline{111612}$ & Aspen & 分脰湶 & 米趐(モ) & & & & & & \\
\hline$\underline{111720}$ & Aspen & 探集地 & $-7)-1$ & 林っ巾 & & & & & \\
\hline$\underline{111729}$ & Aspes & 抹果曰 & 新國仕圭 & & & & & & \\
\hline$\underline{111730}$ & Aspen & 刀和世百 & 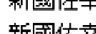 & & & & & & \\
\hline$\underline{111731}$ & Aspe: & 拝供苩 & 利國任華 & & & & & & \\
\hline$\underline{111747}$ & Assoe: & 怢夏 & $\mathrm{RKG}-1$ & & & & & & \\
\hline$\underline{111748}$ & Assoe. & 培地 & Potato d & gar (ha & (Fotato 200g & r decocti & $20 g$ & ggr & \\
\hline$\underline{111749}$ & Aspen & & $17-20 \mathrm{gg}$ & vater 14 & & & & & \\
\hline$\underline{111750}$ & Aspen & 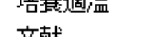 & $20 \mathrm{C}$ & & & & & & \\
\hline$\underline{111751}$ & Asoes & X佣 & 利國任并 & 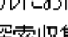 & 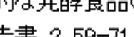 & 公问且 & 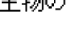 & & \\
\hline$\underline{111831}$ & Aspoes & 配布申议 & -100 & 年 & 百, 2,00 & & & & $=$ \\
\hline 111832 & Aspees & 癿而中运 & 니 & & & & & & $\underline{v}$ \\
\hline$\underline{111833}$ & Aspere. & & & & & & & & 4 \\
\hline
\end{tabular}

図 3 微生物株ウェブカタログの検索画面と詳細情報画面

A, 検索システム画面の例; B, ヒットした微生物株の一覧と, 詳細情報を表示する画面（図中の内部ウィンドウ）. （画像は農業生物資源ジーンバンクのサイトより） 


\section{その他のサービス}

$\mathrm{CC}$ の基本的な業務は上述の通りであるが，それ以外に もさまざまなサービスをユーザに提供している，以下にそ のいくつかを紹介する.

モノグラフの出版・公開:保存微生物株についてのマニュ アルやモノグラフ(その微生物株もしくは微生物種の総説, 解説）を作成し，それを冊子体もしくは電子ファイルとし て公開し, 微生物株の更なる利用を促進している ${ }^{25}$.

メールマガジン：紙媒体のニュースの代わりにメールマ ガジンをユーザに発行し，新たに公開した微生物株の情報 をいち早くユーザに届ける，文字だけのメールマガジンに 新たに写真や図表を付け，それをサイトで公開し，一種の 知識データベースとして活用することも可能である ${ }^{26)}$.

微生物取扱い講習会：CC の日常業務である，微生物の 取り扱いについての講習会を開き，ユーザの微生物取扱い 技術の向上に寄与している。対面のサービスであり，情報 が相手からも得られる，という利点を有する

セーフティデポジット：CC は業務として微生物を保存 しているため，保存技術およびそのための設備が他の研究 施設よりも格段に優れている。それらを利用して，研究者 から微生物株を預かり，それを安定的に長期にわたり保存 するという「貸金庫」的なサービスである，

\section{微生物株の利用に際して}

微生物株の分讓依頼時および受領時の注意点をいくつか 挙げたい.

ユーザはカタログ(最近ではオンラインカタログが主流) で微生物株を検索し，CC に分譲を依頼する。分譲依頼書 やサイトなどに分譲した微生物株に係る権利や注意事項が 明示されているのでそれを十分確認することが必要であ る。特に留意すべき点は 2 点, 1 つは, 微生物株の権利は 多くの場合 CC（もくしは寄託者）側が保有しており，CC から分袞を受けた微生物株は第三者へ譲渡してはならない こと.もうひとつは，通常は研究目的で分譲しているCC がほとんどであり, 特許取得や産業に利用したい場合には, 事前に分譲元の CC との調整が必要になることである。

分譲依頼に際しては，依頼書以外にも同意書その他が必 要になることもある. 特に, 分変依頼する微生物株の権利 を寄託者が有している場合には寄託者からの分讓許可，そ れが病原微生物（特に外国産）の場合には関係機関への許 可申請や届出が必要になることがある。詳細については CCに照会するとよい.

次に微生物株を受領した時にユーザがまず行わなければ ならないことを以下に簡単に記す。受領後, 可及的速やか にその微生物株を培養し，異常が無いことを確認する必要 がある。受領した標品の状態でも，通常は冷蔵庫に保管す ればかなりの期間，安定に保存できるが，それでも輸送中
に破損したり，死滅したりする危険性は否めない。受領し てからしばらくして異常に気付いたとしても，交換できな い場合があるので，早めに確認をしておきたい。確認の方 法については，微生物株とともに送られてくる説明書を参 考にしていただきたいが，一般的には以下のような方法が 用いられる。

凍結乾燥品（L-乾燥品を含む）はガラスアンプルの形で 送付されるが, その場合, ガラス表面を $70 \%$ エタノールで 拭いた後, アンプルカッターややすり（ガラスにあたる部 分はあらかじめ $70 \%$ エ夕ノールで拭いおく）でガラス表 面を軽く傷を付け，開封する必要がある。滅菌水や液体培 地を滅菌したパスッールピペットで吸い上げ，アンプル内 の凍結乾燥菌体に加え，その懸濁液を適当な平板培地に落 とし，画線培養する（図 $2 \mathrm{H}$; この操作を復元と呼んでい る $)^{28)}$. 糸状菌の凍結標品の場合, 解凍した保存標品（通常 はプラスチックチューブ）か，スラント培養したものが送 付されてくる，チューブに入っている場合は，中の寒天片 を適当な平板培地に置き, 培養する ${ }^{29}$. いずれも, 凍結・解 凍・復元の過程で, 細胞が損傷を受けているため, 通常よ りも長く培養することが必要な場合もある（経験上，多く の保存標品は，通常の培養期間で増殖する).

\section{おわりに}

最後にお願いであるが，もし，微生物株を用いた研究を 論文で発表された場合，再現性の確認や関連研究の更なる 発展のためにその微生物株を日本国内のいずれかの CCに 寄託して頂きたい，とはいうものの，発酵関係の微生物の 場合，特許や産業利用に関わるものも多く，分譫が前提の $\mathrm{CC} へ$ の寄託が困難な場合もある。そういう場合には，特 許権が切れた時や研究が完了した時にCCに微生物株を寄 託するとよい，微生物株の保存は個人や研究室で行うには 非常に大きな労力がかかり，それが理由で死滅させてしま うかもしれない。失う前に寄託をお願いしたい。また， CC から分譲を受けた微生物株で論文を発表した場合に は，その微生物株の登録番号を論文に記載し，論文の書誌 情報を分䜇元の CC に連絡するとよい，論文情報も微生物 株に関連付けて公開しているCC も多いので，論文の宣伝 にもなる。図 1 にユーザからのフィードバックで示されて いるように，「持ちつ持たれつの関係」，それがCC と研究 者の互いのメリットが相乗的に高まっていく健全な関係で ある。

\section{文献}

1）宮下 進，遺伝資源研究一最近の展開。農業技術，50, 2124 (1995).

2）長峰 司, 武田尚人, 國廣泰史, 農林水産ジーンバンク, 蛋 白質核酸酵素，44, 71-75 (1999)

3）駒形和男, 最近の欧米のカルチャー・コレクション。日本 微生物資源学会誌, 12,87-90 (1996). 
4) 駒形和男, 日本微生物保存機関連盟加 日本微生物資源学 会へ。日本微生物資源学会誌, 17, 53-62 (2001).

5）駒形和男, わが国のカルチャーコレクションの系譜と活動. 日本微生物資源学会誌, 20, 65-72 (2004).

6）長谷川武治, JFCC 誕生のころ. 日本微生物資源学会誌, $\mathbf{1 7}$, 49-51 (2001).

7）西山幸司, 久保村安衛, 三木信雄, 遺伝資源事業における微 生物株の保存方法 1. 細菌の保存法. 農業生物資源研究所 研究資料, 2, 1-12 (1991).

8）坂根 健, 西井忠止, 伊藤忠義, 見方洪三郎, L-乾燥法によ る微生物株の長期保存法. 日本微生物資源学会誌, $12,91-$ 97 (1996).

9) Wakimoto, S., Utatsu, I., Matsuo, N. and Hayashi, N., Multiplication of Pseudomonas solanacearum in pure water. Annals of the Phytopathological Society of Japan, 48, 620-627 (1982).

10）三木信雄，久保村安衛，西山幸司，遺伝資源事業における微 生物株の保存方法 2. 糸状菌・酵母の保存法. 農業生物資源 研究所研究資料, 4, 27-37 (1992).

11) Nishii, T. and Nakagiri, A., Cryopreservation of Oomycetous fungi in liquid nitrogen. IFO Research Communications, 15, 105-118 (1991).

12) Ko, W.-H., Long-term storage and survival structure of three species of Phytophthora in water. Journal of General Plant Pathology, 69, 186-188 (2003).

13) Nagai, T., Ideno, A., Tsuge, M., Oyanagi, C., Oniki, M., Kita, K., Horita. M., Aoki, T., Kobayashi, T. and Tsuchiya, K., Preservation of fungi in an atmosphere over liquid nitrogen after uncontrolled freezing. Microbiology and Culture Collections, 16, 13-22 (2000).

14) Nagai, T., Tomioka, K., Takeuchi, K., Iida, M., Kawada, M. and Sato, T., Evaluation of preservation techniques of microorganism resources in the MAFF Genebank. JARQ-Japan Agricultural Research Quarterly., 39, 19-27 (2005).

15) Takeya, M., Yamasaki, F., Uzuhashi, S., Aoki, T., Sawada, H., Nagai, T., Tomioka, K., Tomooka, N., Sato, T. and Kawase M., NIASGBdb : NIAS Genebank databases for genetic resources and plant disease information. Nucleic Acids Research, 39 (suppl 1), D1108-D1113 (2011).

16) Takeya, M., Yamasaki, F., Uzuhashi, S., Kumagai, M., Sawada, H., Nagai, T., Tomioka, K., Sato, T., Aoki, T. and Kawase, M., Development of a database of plant diseases in Japan and a system for making microorganism genetic resources and their DNA sequence data available to the research community. JARQ-Japan Agricultural Research Quarterly. 46, 193-198 (2012).
17）市原正巳, 伴さやか, 鈴木健一朗, 菅原秀明, JSCC オンラ インカタログのご紹介．日本微生物資源学会誌， $22,141-$ 146 (2006)

18）大和田勉， BRC/JCM における微生物株の保存および在庫 管理. 日本微生物資源学会誌, 21, 73-76 (2005).

19）岡根 泉, $-80^{\circ} \mathrm{C}$ フリーザーによる糸状菌凍結保存株の管 理体制について。 日本微生物資源学会誌，21, 77-82 (2005).

20）伊藤純子, 千葉大学真菌医学研究センターにおけるアンプ ルおよびストックデータ管理について。日本微生物資源学 会誌, 21, 69-72 (2005).

21）永井利郎, データベースを用いた在庫管理一NIAS ジーン バンクの場合一. 日本微生物資源学会誌，21, 83-86 (2005).

22）森 史, 国立環境研究所 NIES コレクションにおけるバー コードを用いた凍結試料管理. 日本微生物資源学会誌, 21 , 87-91 (2005)

23）余明順, 万国郵便条約およびバイオセーフティ(平成 13 年 度カルチャーコレクション実務担当者会議報告). 日本微生 物資源学会誌, 18, 57-59 (2002).

24）余明順, 改訂された感染症法と病原微生物の移動・運搬に 関する規則。日本微生物資源学会誌， 23, 35-40 (2007).

25）澤田宏之, 永井利郎, 佐藤豊三, 富岡啓介, 山崎福容, 竹谷 勝，青木孝之，農業生物資源ジーンバンク事業における微 生物遺伝資源利用マニュアルの刊行. 日本微生物資源学会 誌, 28, 165-169 (2012).

26）中川恭好, NBRC が配信するメールマガジン「NBRC ニュー ス」について. 日本微生物資源学会誌，28，155-157 (2012).

27）岡田元, 理研 BRC-JCM で開催された技術研修. 日本微 生物資源学会誌, 28, 159-164 (2012).

28）永井利郎, 飯田元子, 植物病原細菌の保存法. 微生物遺伝 資源利用マニュアル，17, 33-40 (2004).

29）富岡啓介, 永井利郎, 飯田元子, 佐藤豊三, 植物病原菌類の 保存法. 微生物遺伝資源利用マニュアル， 17, 23-32 (2004).

\section{CC および関係組織の URL}

i ) MAFF (NIAS), http://www.gene.affrc.go.jp/index_j.php

ii ) ATCC, http://www.atcc.org/

iii) CBS, http://www.cbs.knaw.nl/

iv) IMI, http://www.cabi.org/

v) WFCC, http://www.wfcc.info/

vi) JSCC, http://www.jscc-home.jp/

vii) NBRC, http://www.nbrc.nite.go.jp/

viii) JCM, http://www.jcm.riken.jp/

(平成 25 年 3 月 6 日受理) 